Canadian University Music Review

Revue de musique des universités canadiennes

\title{
Curtis Price, ed. Purcell Studies. Cambridge: Cambridge \\ University Press, 1995. xii, 305 pp. ISBN 0521-44174-9 \\ (hardcover)
}

\section{Erich Schwandt}

Volume 18, numéro 2, 1998

URI : https://id.erudit.org/iderudit/1014657ar

DOI : https://doi.org/10.7202/1014657ar

Aller au sommaire du numéro

Éditeur(s)

Canadian University Music Society / Société de musique des universités canadiennes

ISSN

0710-0353 (imprimé)

2291-2436 (numérique)

Découvrir la revue

Citer ce compte rendu

Schwandt, E. (1998). Compte rendu de [Curtis Price, ed. Purcell Studies.

Cambridge: Cambridge University Press, 1995. xii, 305 pp. ISBN 0521-44174-9

(hardcover)]. Canadian University Music Review / Revue de musique des

universités canadiennes, 18(2), 90-93. https://doi.org/10.7202/1014657ar

All Rights Reserved (C Canadian University Music Society / Société de musique des universités canadiennes, 1998
Ce document est protégé par la loi sur le droit d'auteur. L'utilisation des services d'Érudit (y compris la reproduction) est assujettie à sa politique d'utilisation que vous pouvez consulter en ligne.

https://apropos.erudit.org/fr/usagers/politique-dutilisation/ 
for musicians who are interested in historical performance, and there is advice for musicians in general. The topics considered include voice-quality, care of the voice, the art of practising, the art of breathing, and the art of performing everything well. In addition, there is a thorough discussion of nuance in performance, rhythmic liberties, ornamentation, improvisation, and taste-all of these issues are addressed at length, and in depth.

The book has very few printing errors. On p. 109, line 14, "faulty" has been omitted. On p. 110 the example is reprinted from p. 109 by mistake. On p. 125, the last beat of the example needs another beam. On p. 269, note 30, read "an error."

Every performer interested in eighteenth-century music will find Julianne Baird's book to be a welcome and useful reference book.

Erich Schwandt

Curtis Price, ed. Purcell Studies. Cambridge: Cambridge University Press, 1995. xii, 305 pp. ISBN 0521-44174-9 (hardcover).

Introduction: Curtis Price, "In Search of Purcell's Character"; 1. Robert Thompson, "Purcell's Great Autographs"; 2. Robert Shay, "Purcell as Collector of 'Ancient' Music: Fitzwilliam MS 88"; 3. Rebecca Herissone, "Purcell's Revisions of his own Works"; 4. Curtis Price, "New Light on Purcell's Keyboard Music"; 5. Peter Holman, "Purcell and Roseingrave: A New Autograph"; 6. Bruce Wood, “'Only Purcell e're Shall Equal Blow”; 7. Ian Spink, "Purcell's Odes: Propaganda and Panegyric"; 8. Martin Adams, "Purcell, Blow, and the English Court Ode"; 9. A. Margaret Laurie, "Continuity and Tempo in Purcell's Vocal Works"; 10. Katherine Rohrer, "Poetic Metre, Musical Metre, and Dance in Purcell's Songs"; 11. Andrew Pinnock, "King Arthur Expos'd: A Lesson in Anatomy"; 12. Ellen T. Harris, "King Arthur's Journey into the Eighteenth Century"; Afterword: Janet Snowman, "A Portrait of Henry Purcell."

Purcell Studies is a collection of twelve essays by leading authorities on the music of Henry Purcell (1659-95). Many of the contributors are active as editors for the collected edition of Purcell's music, and have published important books and articles on the composer. These essays are united by a common search for new information about Purcell's musical development and compositional techniques, and, taken together, underscore several important facts: (1) the manuscript sources of Purcell's music, including the three "Great Autograph" volumes, have not been studied as closely as scholars have presumed; (2) the chronology of Purcell's music is, in many cases, still in question; (3) the influence of Purcell on his contemporaries (and their influence on him) has not yet been thoroughly investigated; and (4) the ordinary music lover is still largely unaware of the extent or quality of Purcell's music. Curtis Price, the editor, sums up this last point in his Introduction: 
There is an apparent gap between the high esteem in which musicologists and performers hold his music and the paucity of works in the standard repertory. Only Dido's lament, "Nymphs and Shepherds," and the "Trumpet Voluntary" (actually by Jeremiah Clarke) have entered the canon (p. 1).

The first three chapters are devoted to discussion and analysis of the three "Great Autographs" of Purcell's works. The music in these manuscript books was assembled and copied by Purcell himself; although they have been studied for decades, they have not yet yielded up all their secrets. Robert Thompson makes a thorough analysis of British Library Add. MS 30930, paying close attention to watermarks, rastration, emendations, content, the stages of development in Purcell's handwriting, and so forth. When the manuscript was last rebound in 1895, separate folios and various gatherings were hopelessly jumbled, and the resulting volume is, in many cases, confused and incoherent. Thompson proposes a complete reordering of the manuscript, and his reconstruction of the volume will repay careful study. He gives us some new ideas about the characteristic features of the "Great Autographs":

[T] hey are not retrospective collections of works in a form the composer thought definitive. ... the three manuscripts have more the character of a workshop than a museum. ... they neither render all secondary sources redundant nor provide a solution to all editorial problems. They offer us ... a privileged insight into Purcell's working life as both performer and composer (p. 20).

Robert Shay shares the fruits of his close study of Fitzwilliam MS 88, Purcell's collection of anthems by his predecessors, his contemporaries, and himself. Shay's detailed study of the manuscript and his remarks about its genesis will surely be the basis for all future research based on its repertory. According to Shay, Purcell acquired the volume about 1682 (p. 43) and used it as an anthology of works by older composers. In it, he wrote out music from partbooks into full score, correcting the textual underlay and amending the musical text as he went. Purcell's own anthems in Fitzwilliam 88 are traditional ones, perhaps to keep the style of the volume uniform. Shay has determined that the volume was begun by Dr. John Blow, and has thus documented a new and interesting connection between the two contemporaries.

In her chapter, Rebecca Herissone examines the "Great Autographs" for the information they can yield about Purcell's revisions of his own works, presenting many useful and well-chosen examples to illustrate her points. She states:

[T] he greatest proportion of the major revisions to the early works include the alteration of the harmonic language. Although inevitably an over-simplification, [Long's] statement that Purcell's harmonic language underwent a "gradual process from the daring harmony, contrapuntally derived dissonance, and frequent modality of the earlier works towards a more tonally directed harmony and a simplified harmonic texture in the later works" is borne out by most of the large-scale revisions he made in his early works (p. 66). 
Curtis Price reports on a newly discovered manuscript collection of almost forty keyboard pieces in the handwriting of Purcell and Draghi. The volume apparently was owned by a well-to-do London family, and the children's music teacher (Purcell, and later Draghi) entered pieces at the lessons. The manuscript, which contains five unknown pieces by Purcell, will undoubtedly yield up more secrets when it is carefully studied.

Peter Holman reports on Purcell's copy of a Roseingrave anthem. He concludes that the piece was hastily copied by Purcell as a favour to Roseingrave, and was posted to him for his use at Gloucester or Winchester.

In his essay, Bruce Wood suggests that Blow and Purcell mutually inspired each other by interchanging musical ideas and techniques of composition. Each composer, in trying something new, seemed to be daring the other to outdo him. Wood gives many examples that show convincingly how Blow and Purcell "borrowed" ideas from each other, adapted new kinds of instrumentation, and generally spurred each other on.

Ian Spink gives an enlightening "tour" of Purcell's Odes, and emphasises their "political" content. Purcell's twenty-four Odes, as Spink says:

span the years 1680-1695 and represent a conspectus of his development as a composer from the age of twenty-one until his death (p. 145).

A chronological list of Purcell's Odes, including lost works, closes the essay. Martin Adams focusses on the structure and style of the Odes of Blow and Purcell. He illustrates his essay with tables that show large-scale harmonic plans as well as large-scale contrasts of metre and texture. Like Bruce Wood, Adams points out the importance of the constant interchange of ideas between Blow and Purcell.

Margaret Laurie assesses the problem of continuity and tempo in Purcell's vocal works. Musical illustrations are all carefully chosen, and serve as points of departure for her enlightening remarks on metre and tempo. She sorts out the possible meanings of Purcell's various time signatures and finds that the signs can vary in meaning from piece to piece; moreover, there is no absolute tempo implied by any time signature. She considers what theorists such as Playford, Malcolm, and Muffat say about tempo and what Purcell the composer does. Laurie concludes that Purcell's changes of metre within a piece have a meaning that the good performer can discover. Her remarks on tempo make good sense.

Katherine Rohrer demonstrates that various poetic metres, in and over themselves, suggested particular kinds of musical settings to Purcell; she calls them "lyric" and "declamatory." In addition, certain kinds of poetry called for particular rhythmic gestures, many of them being allied to the rhythmic patterns of the dances in favour in Purcell's time: the minuet, gavotte, passepied, bourrée, and so forth. Her concluding remarks sum up her findings, and underscore the continuing importance of the French Court Dance in the music of Purcell: 
[D]ance types were much more prominent in the composer's vocal works than has been previously noted. ... Purcell's affection for the dance types in his big stage works complicates the received idea that his later career was shaped by a turn away from French styles and towards the Italian. (p. 240)

The last two essays explore Purcell's King Arthur (1691). Andrew Pinnock probes the libretto for its political references and its basis in the legends of "Old England." Although "some bits [of King Arthur] are missing, some corrupt, and it is not clear where some should go" (p. 243), Pinnock thinks it might be possible to reconstruct Purcell's original version. In fact, Pinnock's close study of Dryden's libretto reveals that there is probably a lot less music missing from King Arthur than editors and scholars have supposed.

Ellen Harris traces the revivals of King Arthur in the eighteenth century, as well as its transformation (with additions and substitutions) by Arne and Garrick. The performance history of King Arthur is fairly complex; she assesses the relevant documents and speculates on the musical contributions by Arne as well as his remodelling of Purcell's music.

Purcell Studies is an up-to-date guide to the issues that Purcell scholars are addressing. It contains a number of ingenious solutions to problems posed by Purcell's music. Every reader will find something in the book that will be of interest.

Erich Schwandt

Juliane Brand and Christopher Hailey, eds. Constructive Dissonance: Arnold Schoenberg and the Transformations of Twentieth-Century Culture. Berkeley, Los Angeles, and London: University of California Press, 1997. xviii, 232 pp. ISBN 0-520-20314-3 (hardcover).

Considering that most of Arnold Schoenberg's musical compositions are rarely performed or recorded, humanist scholars are apt to regard the very notion of Schoenberg studies as peripheral to research on Western culture. Yet the engaging thesis of this book is that understanding Schoenberg is vital to the cultural historiography of the countries where he lived. As ironically suggested by the book's title, the essays collected here thematicize the discords in Schoenberg's life and demonstrate that they are among the building blocks of twentieth-century culture. The fundamental claim is that, despite where he has customarily been placed in history, Schoenberg's path-breaking importance lies not in having invented an influential and infamous method of composing music but in his engagement with the pluralistic social, religious, political, artistic, and educational forces of our century. The evidence arises in the course of close examinations of Schoenberg's milieu, his modes of thinking, and the implications of these for the present day. Musical examples and specifically musical concepts and terminology, where called for in some essays, are kept to a minimum. Therefore, here is a book that can and should be read not only by those specifically interested in Schoenberg's life and creative output but by anyone interested in twentieth-century cultural ideologies. 